\title{
Spinoza and Republicanism
}

Raia Prokhovnik

Palgrave Macmillan, Basingstoke, 2004, $x+280 p p$.

ISBN: 0333733908.

Contemporary Political Theory (2005) 4, 471-472. doi:10.1057/palgrave.cpt.9300211

The fact that this book cannot easily be categorized turns out to be one of its main merits. At one level, it is a study of the development of Dutch republican thinking, a topic that turns out to be elusive and complex. At a second level, it is an investigation into some of the specifics of Spinoza's political thinking, especially with regard to sovereignty and liberty. But behind all this, Raia Prokhovnik makes a strong appeal to a historicized approach to political theory, to a resistance to decontextualized analysis, and to an appreciation in particular of the subtleties gained when the analysis of political theory is conducted through the prism of variegated political experience.

Readers expecting a treatise on Spinoza will not find what they are looking for. Indeed, Spinoza only begins to assert himself on the text from p. 168. But that is precisely the intriguing aspect of Prokhovnik's approach. For, to the conventional contextual methods anchored in narrative and discourse, she adds another - that of historiography itself as context. This is a profoundly hermeneutic reading of Spinoza and his times, and it recognizes, albeit implicitly, that the reconstruction of a theme such as republicanism is always executed through the eyes of past and present reconstructors. Prokhovnik has consequently mastered an impressive array of historical commentary, and she weaves her way judiciously through a welter of opposing and overlapping standpoints in order to tease out her position, modestly but increasingly emphatically stated.

Spinoza emerges from this study as a thinker deeply anchored in the political beliefs and practices of his time, while simultaneously disenchanted with other philosophical approaches, such as Hobbes's, and exploring solutions beyond them. This would have come as a surprise to his contemporaries, who went out of their way to disown his radicalism and hereticism on a number of fronts. While historians of ideas, and certainly analytical philosophers, measure Spinoza against other 'classic' thinkers, he mainly makes sense, argues Prokhovnik, as a theorist who was 'deeply entrenched in the political culture of provincial and city-state practice and aspirations, and used humanist and republican texts in an entirely supporting role' (p. 255). In that, he mirrored the Dutch insular Sonderweg, relying on its own institutions and processes. The book sketches a detailed historical backdrop of the 16th and 17th centuries around the Revolt and the ensuing republic, resulting in a Holland-centric 
United Provinces under De Witt's regime. Later chapters contrast those developments with English republicanism.

Spinoza's cogitations on sovereignty, explicitly in the Tractatus TheologicoPoliticus and implicitly - under the headings of dominion and authority - in his posthumous Tractatus Politicus, must be seen in that light, argues Prokhovnik. The Hobbesian influence needs to be balanced by a recognition of the practical restraints on sovereignty, the salience of which Spinoza saw in the effective distribution of political power among a number of cities implementing local government and linked through a commonwealth, and in the exclusion of the Orange prince. Spinoza's parallel move from endorsing democracy as an ideal in the first work to preferring a confederate aristocracy that would minimize the perils of corruption in the second combines an unease with popular sovereignty and universal reason with a plain rejection of the Hobbesian Leviathan in the name of a constrained political liberty.

As for republicanism, Spinoza dances at the edges of this complex set of ideas. A republic-cum-commonwealth could take different forms of government, and Prokhovnik's admonitions to note the variegated ranges of republicanism require careful attention, when political philosophy has in recent years offered us unitary, overarching models. Thus, she is critical of Pettit's definition that emphasizes a non-arbitrary form of freedom because it leaves out the notion of collective self-government that was so central to the Dutch tradition. There is no simple way of defining Spinoza's republicanism because the republican tradition he knew was irreducible to such simplification. It had to do with decentralized privileges, the respect of difference and civic independence (but not civic humanism) in a loosely communal constitutional framework. If it was ill-theorized it reflected the then anti-theoretical bent of a series of practices that are currently forced under the umbrella term 'republicanism'.

If Spinoza emerges from this study as a less rigorous, and occasionally more contradictory, thinker-in-making than his illustrious English contemporary, Hobbes, it may well be the result of a mixture of his personal insecurities and the cautious pragmatics he imbibed from Dutch political culture. Prokhovnik has engaged in a courageous and controversial exercise that may not, I suspect, satisfy some purist Spinoza scholars but illustrates the benefits of her alternative approach in locating and decoding themes that are invisible from other perspectives.

Michael Freeden University of Oxford, UK. 